\title{
IMPLEMENTASI MANAJEMEN PENDIDIKAN MODEL PESANTREN DALAM MENCETAK ULAMAUL AMILIIN, ULAMAUL MUTTAQIIN, DAN ULAMAUS SHOLIHIN (Penelitian di Pondok Pesantren Al-Intiqol Cianjur)
}

\author{
MASPUROH \\ Dosen STIT Al-Azami Cianjur \\ hmaspuroh@gmail.com
}

Received: 21/01/2019, Accepted: 23/01/2019, Published: 28/01/2019

\begin{abstract}
Education in Islamic boarding schools is the oldest education in Indonesia that has given birth to national movement figures and community leaders who have a big contribution to the Indonesian nation, especially in efforts to educate and form a perfect soul, various problems. At least still struggling on several things, namely : first; to find out how the learning process was carried out in this Islamic boarding school because it was constrained by the limited facilities and infrastructure of the male santri learning room and the office space of the Asatidz and Asatidzah. Second; to find out the use of curriculum used in the implementation of the learning process in Al-Intiqol Islamic boarding school. Third; to find out the learning methodology used to achieve the goals of education in Al-Intiqol Islamic boarding school in Cianjur. The research method uses a field study with a qualitative approach, which will produce descriptive data that can be in the form of oral or written information from informants and resource persons. While the research steps include through observation, interviews, and documentation. The results of the research at the Salafiyah Islamic Boarding School in Al-Intiqol, related to the content standard, namely the curriculum is good and even meets the pesantren standard, which is favored in monotheistic aspects. continued his service in the Cianjur prison and opened the pesantren independently.
\end{abstract}

Keywords: implementation, boarding school, management, printing Islamic Scholar.

\begin{abstract}
ABSTRAK
Pendidikan pada pondok pesantren termasuk pendidikan tertua di Indonesia yang telah melahirkan para tokoh pergerakan nasional serta para tokoh masyarakat yang memiliki andil besar terhadap bangsa Indonesia khususnya dalam upaya pencerdasan dan pembentukan jiwa yang sempurna. Berbagai permasalahan tersebut, setidaknya masih terjadi pada beberapa hal, yaitu: pertama; untuk mengetahui bagaimana proses pembelajaran yang dilaksanakan di pondok pesantren ini karena terkendala keterbatasan sarana dan prasarana ruang belajar santri putra dan ruang kantor para asatidz dan asatidzah. Kedua; untuk mengetahui penggunaan kurikulum yang digunakan dalam pelaksanaan proses pembelajaran di Pondok Pesantren Al-Intiqol. Ketiga; untuk mengetahui metodologi pembelajaran yang digunakan guna
\end{abstract}


tercapainya tujuan pendidikan di Pondok Pesantren Al-Intiqol Cianjur. Metode penelitian menggunakan studi lapangan dengan pendekatan kualitatif, yang nantinya akan menghasilkan data deskriptif yang bisa berbentuk lisan maupun tulisan dari informan dan narasumber. Sedangkan langkahlangkah penelitian diantaranya melalui observasi, wawancara, dan dokumentasi'. Hasil penelitian di Pondok Pesantren Salafiyah Al-Intiqol, terkait standar isi, yakni kurikulum sudah bagus bahkan sudah memenuhi standar pesantren, yang diunggulkan dalam aspek IImu tauhid, Metodologi cenderung menggunakan kontektual disesuaikan dengan sarana yang ada, dan evaluasi sudah bagus di antaranya ada beberapa alumni yang melanjutkan pengabdian kiyainya di Lapas Cianjur dan membuka pesantren secara mandiri.

\section{A. PENDAHULUAN}

Allah S.W.T. menciptakan manusia sebagai makhluk pilihan yang paling sempurna dengan segala kelebihannya, kelebihan yang dimiliki manusia adalah akal pikiran atau nalar. Dengan nalar diharapkan manusia mampu manjadi khalifah di muka bumi, dalam artian manusia bisa memelihara dan memanfaatkan segala apa yang Allah ciptakan untuknya. Pendidikan pada pondok pesantren salafiyah merupakan lembaga sosial kemasyarakatan yang menjadi ciri khas lembaga pendidikan Islam tradisional terbesar di belahan bumi Nusantara baik di desa maupun di perkotaan (Wahid, 1995: 39-60).

Pendidikan pada pondok pesantren juga dikategorikan sebagai pendidikan tertua di Indonesia yang telah melahirkan tokoh-tokoh pergerakan nasional serta tokoh-tokoh masyarakat yang memiliki andil besar tehadap bangsa Indonesia khususnya dalam upaya pencerdasan dan pembentukan jiwa yang sempurna. Menurut sejarah perkembangan pondok pesantren menunjukkan bahwa lembaga ini tetap eksis dan konsisten melaksanakan fungsinya sebagai pusat pengajaran ilmu-ilmu agama, untuk melahirkan para kader ulama, guru agama, mubaligh, tokoh politik, dan lain-lain yang sangat dibutuhkan masyarakat.

Seiring dengan perkembangan zaman dan cepatnya kemajuan ilmu pengetahuan dan teknologi, serta arus informasi global, pendidikan pada pondok pesantren salafiyah, juga mengalami perubahan dalam rangka penyesuaian, khususnya menyangkut kurikulum, tujuan, kegunaan, pemahaman, serta metode pembelajarannya dalam pesantren (Haidar Putra Daulay, 2007: 62-63).

Melihat pada latar belakang tersebut, maka pelaksanaan supervisi pendidikan yang selama ini hanya 
dilakukan di lingkungan sekolah umum dan madrasah, nampaknya perlu pula dilakukan di pesantren salafiyah, walaupun berbagai prinsip dasarnya sama. Pendidikan merupakan salah satu upaya untuk membangun dan meningkatkan mutu SDM menuju era globalisasi yang penuh dengan tantangan sehingga disadari bahwa pendidikan merupakan sesuatu yang sangat fundamental bagi setiap individu. Oleh karena itu, kegiatan pendidikan tidak dapat diabaikan begitu saja, terutama dalam memasuki era persaingan yang semakin ketat, tajam, berat pada abad millenium ini (Haidar Putra Daulay, 2007: 62-63).

Dunia pendidikan di Indonesia masih diliputi berbagai permasalahan, setidaknya masih berkutat pada beberapa hal, yaitu: pertama; belum optimalnya kegiatan pembelajaran karena terkendala keterbatasan sarana dan prasarana terutama di lembaga pendidikan yang terletak di kota kecil dan pelosok. Kedua; keberadaan data nasional yang diperoleh dari hasil ujian nasional, tidak sepenuhnya didapat melalui proses ujian nasional yang penuh kejujuran. Ketiga; sudah menjadi rahasia umum bahwa masih banyak birokrat di bidang pendidikan yang melakukan korupsi, kolusi, dan nepotisme (KKN) (Baharuddin, 2010: $3)$.

Berbagai permasalahan di atas dapat diidentifikasi terletak pada input, proses ataupun output pada lembaga pendidikan. Hal ini harus segera ditangani dan dicarikan solusi pemecahannya untuk menciptakan pendidikan nasional yang lebih berkualitas. Pesantren, sekolah, dan madrasah merupakan lembaga penyelenggara pendidikan di Indonesia. Masing-masing lembaga pendidikan tersebut telah diatur dan diakui oleh pemerintah dalam Undangundang Nomor 20 tahun 2003 tentang Sistem Pendidikan Nasional. Pesantren ditetapkan sebagai salah satu bentuk lembaga pendidikan keagamaan (Pasal 30 Ayat 4). Sedangkan sekolah dan madrasah merupakan lembaga pendidikan formal yang mempunyai jenjang pendidikan dasar dan menengah yang terterah pada pasal 17 dan 18 ( U.-u. R..2003). Secara historis munculnya sistem pendidikan pesantren, sekolah dan madrasah di Indonesia mempunyai keterkaitan antara satu dengan yang lainnya.

Berdasarkan latar belakang masalah di atas, maka pembahasan 
tentang pendidikan pada pondok pesantren ini, mempunyai beberapa indikator yang menjadi rumusan masalah sebagai berikut:

1. Kurikulum apa yang digunakan dalam pembelajarannya di Pesantren Al-Intiqol Cianjur?

2. Standar kompetensi apa saja yang diunggulkan sebagai ciri khas di Pesantren Al-Intiqol Cianjur?

3. Metodologi atau model apa saja yang digunakan dalam proses pembelajaran di Pondok Pesantren Al-Intiqol Cianjur?

4. Karakteristik seperti apa yang ditanamkan di Pondok Pesantren Al-Intiqol tersebut?

5. Bagaimana cara mengukur atau mengevaliasi hasil pembelajaran santri di Pesantren Al-Intiqol Cianjur?

Berpijak pada perumusan masalah tersebut, maka artikel ini diarahkan untuk menjawab rumusan tersebut dengan pengertan sebagai berikut:

1. Untuk mengetahui kurikulum yang digunakan dalam pembelajarannya di pesantren Al-Intiqol Cianjur.

2. Untuk mengetahui standar kompetensi yang diunggulkan sebagai ciri khas di Pesantren AlIntiqol Cianjur.

3. Untuk mengetahui metodologi atau model yang digunakan dalam proses pembelajaran di pondok pesantren Al-Intiqol Cianjur.

4. Untuk mengetahui karakteristik yang ditanamkan di Pondok Pesantren Al-Intiqol tersebut.

5. Untuk mengetahui cara mengevaluasi hasil pembelajaran santri di Pesantren Al-Intiqol.

\section{B. METODOLOGI PENELITIAN}

Metode penelitian menggunakan studi lapangan dengan pendekatan kualitatif, yang nantinya akan menghasilkan data deskriptif yang bisa berbentuk lisan maupun tulisan dari informan dan nara sumber (Bogdan dan Taylor dalam Ulfatin, 2004: 3). Penelitian kualitatif ini merupakan penelitian yang berusaha dan mencoba mengungkap rahasia, fenomena, ataupun permasalahan di suatu tempat atau lokasi penelitian. Sedangkan langkah-langkah penelitian diantaranya melalui, observasi, wawancara, dan dokumentasi (Sugiyono, 2010: 35). Penelitian kualitatif ini merupakan penelitian yang berusaha dan mencoba mengungkap rahasia, fenomena, ataupun permasalahan di suatu tempat atau lokasi penelitian. Data yang dihasilkan berupa data natural sesuai keadaan yang sebenarnya di lokasi. Penelitian kualitatif ini sangat mementingkan naturalistik dan keaslian 
data yang diperoleh melalui metode yang digunakan.

Rancangan penelitian yang digunakan adalah studi kasus, yang merupakan salah satu bentuk rancangan kualitatif dengan menekankan pada pengungkapan secara rinci dan mendalam terhadap suatu objek dan peristiwa, guna memperoleh pengetahuan tentang subjek dan suatu peristiwa tertentu.

Pendekatan kualitatif jenis studi kasus sering digunakan untuk penyelidikan secara mendalam terhadap individu, kelompok atau institusi tujuannya adalah untuk mempertahankan unsur dari objek dan untuk mengetahui tentang bagaimana dan mengapa bisa terjadi. Studi kasus dapat diartikan sebagai suatu pendekatan dengan memusatkan perhatian pada suatu kasus secara intensif dan rinci. Lokasi penelitian ini adalah Pondok Pesantren AlIntiqol Cianjur yang beralamatkan di Jl. Prof. Moch. Yamin Gg. Darna/Jl. KH. Saleh No.10, Kelurahan atau Desa Sayang, Kecamatan Cianjur, Cianjur 43213, No. Telepon: (0263) 265143 Jawa Barat.

Penelitian ini mengunakan strategi atau pendekatan kualitatif dan jenis penelitiannya adalah deskriptif, karena hanya mencoba membahas dan menyampaikan infomrasi secara sistmatis terkait dengan pengelolaan sebuah pesantren (Kumar, 2011). Tahapan penelitian terdiri dari beberapa tahapan, yaitu: 1) Identifikasi data perkembangan pesantren di Indonesia, Provinsi Jawa Barat, dan Kabupaten Bandung. 2) Penentuan pesantren yang menjadi objek peneltian. 3) Penentuan tipologi pesantren. 4) Mendeskripsikan pengelolaan pesantren dalam rangka menciptakan santri berkualifikasi tafaqquh fi al-dîn dan uswatun hasanah (Sugiyono, 2010: 54).

Seluruh tahapan menggunakan penelitian melalui metode pengumpulan, analisis, dan penyajian data. Pengumpulan data primer menggunakan jenis wawancara langsung dengan ustadz atau penanggung jawab, ustadz atau asatidz dan asatidzah santri. Pengumpulan data sekunder dari bahan dokumentasi untuk memperkaya penulis diperoleh dari laporan instansi Kementerian Agama dan Badan Pusat Statitik Provinsi Jawa Barat, kliping berita elektronik, jurnal ilmiah yang memuat penelitian terdahulu tentang perkembangan pesantren. Analisis dan interpretasi 
data dilakukan selama proses dan selesai pengumpulan data. Analisis data selama pengumulaan data dilakukan dengan menulis pada buku catatan lapangan dan sumber dokumentasi. Sedangkan analisis data pada saat selesai pengumpulan data dilakukan melalui pemutaran ulang rekaman wawancara. Data dianalisis berdasarkan aspek yang menjadi tujuan penelitian. Data hasil analisis disajikan menggunakan narasi, tabel, dan bagan untuk memudahkan pemahaman terhadap hasil penelitian. Waktu pengumpulan data wawancara dan observasi dilakukan pada Juli sampai Oktober 2018 di Pondok Pesantren Salafiyah Al-Intiqol Cianjur.

Peneliti tertarik melakukan penelitian karena Pondok Pesantren AlIntiqol sebagai lembaga pendidikan berupa pondok pesantren dimana dari tahun berdirinya tidak pernah kekurangan santrinya, terutama dari kalangan pelajar yang jauh tempat tinggalnya atau dari luar kota. Inilah salah satu tujuan orangtua dalam memasukkan anaknya di Ponpes ini untuk menggali pendidikan agama maupun pendidikan umum. Ponpes AlIntiqol Cianjur ini mampu menonjolkan diri sebagai pondok pesantren yang lebih moderat dalam hal menerapkan kebijakan menampung santri dan santriah yang sedang melanjutkan di sekolah formal di luar lingkungan pesantrennya. Hal ini salah satu kebijakan yang dipandang terbuka dan memudahkan masyarakat dalam menitipkan anak-anaknya.

\section{PEMBAHASAN}

\section{Pengertian Pesantren}

Menurut asal katanya pesantren berasal dari kata "santri" yang mendapat imbuhan awalan "pe" istilah akhiran "an" (Haidar Putra Daulay, 2005) yang menunjukkan tempat, maka artinya adalah tempat para santri. Terkadang pula pesantren dianggap sebagai gabungan dari kata "santri" (manusia baik) dengan suku kata "tra" (suka menolong) sehingga kata pesantren dapat diartikan tempat pendidikan manusia baik-baik (Steenbrink, 1998: 106).

Lebih jelas dan sangat terinci sekali Madjid (1997: 19-20) mengupas asal usul perkataan santri, ia berpendapat, "Santri itu berasal dari perkataan "sastri" sebuah kata dari Sansekerta, yang artinya melek huruf, dikonotasikan dengan kelas literary bagi orang Jawa yang disebabkan karena pengetahuan mereka tentang agama melalui kitab-kitab yang bertuliskan dengan bahasa Arab. Kemudian diasumsikan bahwa santri 
berarti orang yang tahu tentang agama melalui kitab-kitab berbahasa Arab dan atau paling tidak santri bisa membaca Al-Qur'an, sehingga membawa kepada sikap lebih serius dalam memandang agama. Juga perkataan santri berasal dari bahasa Jawa "cantrik" yang berarti orang yang selalu mengikuti guru kemana guru pergi menetap (istilah pewayangan) tentunya dengan tujuan agar dapat belajar darinya mengenai keahlian tertentu.

Pesantren juga dikenal dengan tambahan istilah pondok yang dalam arti kata bahasa Indonesia mempunyai arti kamar, gubug, rumah kecil dengan menekankan kesederhanaan bangunan atau pondok juga berasal dari bahasa Arab "Fundũq" yang berarti ruang tidur, wisma, hotel sederhana, atau mengandung arti tempat tinggal yang terbuat dari bambu" (Zarkasy, 1998: 105-106). Pesantren atau lebih dikenal dengan istilah pondok pesantren dapat diartikan sebagai tempat atau komplek para santri untuk belajar atau mengaji ilmu pengetahuan agama kepada kiyai atau guru ngaji, biasanya komplek itu berbentuk asrama atau kamar-kamar kecil dengan bangunan apa adanya yang menunjukkan kesederhanaannya.
Pesantren adalah lembaga pendidikan yang asli (indigeneous) dan berakar kuat dalam masyarakat Indonesia. Pesantren sebagai lembaga yang memiliki kontinuitas karena memelihara tradisi Islam yang dikembangkan ulama dari masa ke masa. Pesantren juga memiliki daya tahan terhadap dinamika perubahan zaman modern saat ini. Kekuatan ini yang menjadikan kebanyakan masyarakat Islam Indonesia khususnya menggantungkan harapannya pada peran pesantren sebagai pusat pengembangan di berbagai bidang sosial keagamaan di samping fungsi awalnya sebagai lembaga pendidikan tradisional (Madjid, 2010: 19-21).

Ditinjau dari sejarahnya, pesantren telah memainkan peran dan melahirkan tokoh penting dalam membangun peradaban di Indonesia dimulai dari Peradaban Melayu Islam di Nusantara antara abad ke 13 dan ke 17 melalui tokohnya Hamzah Fansuri, Syamsuddi As-Sumaterani, Abdurrauf As-Singkel, dan Nuruddin Arraniri (Dhofier, 2015). Pejuang kemerdekaan Indonesia yang dilahirkan pesantren adalah KH. Ahmad Dahlan, KH. Hasyim Asyari, RA Kartini (Nashiruddin, 2015), dan pemimpin bangsa Abdurrahman Wahid. Gus Dur 
adalah alumni pesantren Tegalrejo, Tambak Beras (Wahid, 1983). Banyak lagi tokoh kepemimpinan nasional alumni pesantren yang memiliki mutu tinggi dalam hal pemahaman agama (tafaqquh fi al-dîn) dan uswatun hasanah (teladan baik) di bidang lainnya dalam kehidupan bermasyarakat dan bernegara.

Seperti disebutkan di atas, bahwa peran pesantren terus berkiprah di bidang lainya maka tidak mengherankan jika saat ini banyak pesantren yang memiliki karakteristik tertentu, misalnya mencetak Sumber Daya Manusia (SDM) wirausaha (entrepreneurship) (Fauzi, 2012) dan pengembangan sumber daya pangan dan energi baru terbarukan di lingkungan sekitar pesantren (Khoiri, 2016). Sehingga dapat dikatakan bahwa pesantren menjadi lembaga yang efektif bagi pemerintah untuk menerapkan kebijakan dan programnya di berbagai bidang (Tafsir, 2013). Contoh lainnya adalah peran pesantren dalam membantu program pemerintah untuk membendung gerakan radikalisasi agama. Pesantren yang memiliki sikap keagamaan moderat (wasathiyah) menjadi harapan bagi para pemimpin dan masyarakat di negeri ini untuk menjadi solusi damai terhadap berbagai bentuk konflik horizontal dan vertikal karena perbedaan masalah paham keagamaan (Puslitbang Kehidupan Keagamaan, 2010). Terakhir seperti dikatakan (Suharto, 2013), pesantren telah menerapkan konsep pendidikan berbasis masyarakat yang sesungguhnya dengan salah satunya indikatornya mampu memenuhi pendanaannya secara mandiri berbasis pada masyarakat (Wahid, A. 1995: 68).

Perkembangan pesantren di tanah air terus mengalami peningkatan jumlah mencapai puluhan ribu pesantren. Provinsi Jawa Barat adalah salah satu provinsi di Indonesia yang memiliki sejarah perkembangan dan jumlah pesantren terbanyak tersebar di berbagai lokasi dengan karakteristiknya masing-masing. Kini pesantren bukan hanya berciri salaf dan belokasi di pedesaan seperti yang dikenal selama ini, namun juga ada yang berciri khalaf dan berlokasi di perkotaan. Dengan demikian tipologi pesantren sudah bervariasi sekali dan merupakan gabungan dari jenis-jenis pesantren yang ada. Gairah masyarakat untuk memberikan pendidikan berbasis pesantren pada anak-anaknya terus mengalami perkembangan yang signifikan (Hakim, L. 2016). 
Mengingat peran dan kontribusi pesantren melalui santri dan ulamanya dalam mempertahankan kemerdekaan Indonesia, maka Pemerintah saat ini memberikan perhatian lebih terhadap pesantren dengan salah satu indikatornya adalah penetapan 22 Oktober sebagai hari santri (Keputusan Presiden Republik Indonesia Nomor 22/2015 tentang Hari Santri). Perkembangan terkini, pesantren juga telah banyak bekerjasama dengan Kementerian selain Kementerian Agama. Misalnya Kementerian Ketenaga kerjaan memiliki kebijakan pembangunan 1.000 Balai Latihan Kerja (BLK) komunitas di pesantren (Setiawan, 2018) dan Kementerian ESDM bekerjasama dengan pesantren untuk pelatihan dan sertifikasi juru las berstandar International Institute of Welding (IIW) (Tim Komunikasi ESDM, 2011).

Dilihat dari tipologinya, pesantren sudah banyak berkembang jenisnya tidak hanya pesantren salaf tetapi juga pesantren khalaf (modern). Lokasi pesantren juga tidak hanya di pedesaan terpencil, tatapi juga di perkotaan. Pondok Pesantren AlIntiqol Cianjur adalah salah satu pesantren salafi yang berlokasi di tengah kota di Kabupaten Cianjur dan berada di antara ribuan pesantren di Provinsi Jawa Barat. Pesantren ini juga berada di tengah-tengah lingkungan masyarakat umum dan Islam di Jawa Barat. Pesantren yang menjadi subjek penelitian ini akan dideskripsikan tipologi, elemen-elemen pesantren, dan proses pengelolaannya dalam rangka mencapai mutu lulusan yang tafaquh fi al-dîn dan uswatun hasanah untuk mencapai visi dan misi pesantren yakni: Mencetak Ulamaul Amiliin, Ulamaul Muttaqiin, dan Ulamaus Sholihin.

Sebagai pengantar maka tujuan pertama penelitian ini adalah mendeskripsikan konsep pesantren dan perkembangan pesantren di Jawa Barat berdasarkan kajian pustaka.

2. Landasan Historis, Landasan Teoritis, dan Landasan Yuridis a. Landasan Historis Berdirinya
Pondok Pesantren Salafiah Al-
Intiqol Cianjur Pondok Pesantren Al-Intiqol merupakan salah satu pondok pesantren salafiyah yang ada di kota Cianjur tepatnya di Cikidang, Pabuaran Cianjur. Di pesantren ini para santri belajar kitab kuning meliputi kajian fikih, tauhid, nahwu, sorof, dan lain sebagainya. 
Pesantren ini didirikan tanggal 17 Agustus 1989 oleh KH. T Mukhtar Gozali, yang dikenal dengan sebutan Mama Lapas. Pasalnya, selain mengasuh Pesantren Al-Intiqol, beliau aktif dan fokus membina pesantren AtTaubah yang berada di Lapas Cianjur.

Awal berdirinya pesantren ini yaitu dari kegiatan sanlat (pesantren kilat) yang diikuti 333 peserta, ketika beliau selesai menimba ilmu di Pesantren Miftahul Huda, Manonjaya Tasikmalaya, dan sebagian dari peserta sanlat waktu itu ada langsung yang menjadi santri walaupun jumlahnya hanya beberapa orang. Setelah berdiri beberapa tahun pesantren ini semakin terprogram dengan tetap mengkaji kitab kuning yang merupakan prioritas utamanya. Di pesantren ini pembelajarannya dibentuk perkelas meliputi kelas ibtida, dari I-III, tsanawi I-III dan ma'had aly"' (Haidar Putra Daulay. 2007: 62-63).

Kemudian di pesantren ini juga diselenggarakan ujian semester bagi para santri per enam bulan sekali, kegiatan muhadhoroh bersifat mingguan, pengajian harian, pengajian mingguan, pengajian bulanan bagi alumni, dan orang tua santri. Selain itu ada juga program tahunan, yakni khitanan massal dan kegiatan sanlat. Serta program yang jadi bukti keberhasilan santri yakni adanya wisuda bagi para santri yang akan naik ke tingkat yang lebih tinggi.

\section{b. Landasan Filosofis}

Pilar filosofis merupakan pilar yang dijadikan pijakan bahwa pendidikan pesantren di kabupaten Cianjur adalah merupakan gambaran kepribadian para pendiri/para tokoh atau cikal bakal kota Cianjur yang didirikan oleh Dalem Cikundul yang bernama asli Rd. Jayasasana atau R.A. Wiratanu I adalah Bupati Cianjur yang pertama. Rd. Jayasasana merupakan seorang figur ulama besar yang sangat disegani, hingga memperoleh julukan Dalem Cikundul, karena keberadaannya di Kp. Majalaya Cijagang Cikalong Kulon, terletak di pinggir Sungai Cikundul. Kecerdasan dan sikapnya yang arif dan bijaksana, membuat kepribadiannya mudah dikenal oleh warga masyarakat di daerah-daerah sekitar wilayah Cianjur.

Namanya terus mewangi mengharumkan tatar Parahiyangan, samba terus berdakwah menyebarkan agama Islam, kesejahteraan kebersamaan warga masyarakat Cianjur semakin meningkat, hingga akhirnya Sultan Cirebon memberinya gelar R.A. Wiratanu I dan mendapatkan julukan Dalem Cikundul 
sebagai pemimpin pertama di seluruh negeri Cianjur pada saat itu juga mendapat julukan Dalem Mandiri. Belajar agama Islam adalah fardu a'in terutama dalam pengamalannya, maka masyarakat Cianjur dari masa lalu belajar Agama itu merupakan hal yang sudah ditanamkan oleh para leluhur sehingga saat ini pondok pesantren tetap menjadi ciri kepribadian masyarakat Cianjur. Pondok pesantren suatu lembaga yang harus dipertahankan sebagai lembaga pendidkan tafaqquh fiddin melalui sumber pembelajaran pada kitab-kitab kuning yang merupakan ide, cita-cita, dan simbol keagungan dari pondok pesantren di Kabupaten Cianjur (Dadan, E. S. 2008).

\section{c. Landasan Teoretis}

Pesantren merupakan salah satu jenis pendidikan Islam Indonesia yang bersifat tradisional tujuannya untuk mendalami ilmu agama Islam dan mengamalkan sebagai pedoman hidup keseharian. Pesantren telah hidup sejak ratusan tahun yang lalu, serta telah menjangkau hampir seluruh lapisan masyarakat Muslim di Indonesia. Pesantren telah diakui sebagai lembaga lembaga pendidikan yang telah ikut mencerdaskan kehidupan bangsa. Pada masa kolonialisme berlangsung, pesantren merupakan lembaga pendidikan agama yang sangat berjasa bagi masyarakat dalam mencerahkan dunia pendidikan.

Pada awal tahun 1970-an, Mukti Ali, Menteri Agama pada saat itu, menyerukan adanya peremajaan sistem nilai pesantren dan berkeinginan agar pesantren bisa bertidak sebagai agen perubahan dalam masyarakat Indonesia supaya memfasilitasi pengembangan masyarakat. Dalam menjelaskan visinya Mukti Ali, yang dikenal sebagai seorang pemikir yang cukup progresif dan seorang pembimbing yang baik bagi kaum intelektual muda, beliau mengutif salah ayat Al-Qur'an "Jadilah di antara kamu sekelompok orang yang akan melakukan pekerjaan baik dan melaksanakan kewajiban agama dan mematuhi apa yang dilarang dalam agama" (Jurnal Pusaka 16 julidesember 2015). Mukti Ali memilih teks ini untuk menunjukkan bahwa kelompok-kelompok kecil yang terdiri dari pemuka-pemuka agama yang berpandangan jauh ke depan dan berkomitmen dapat memainkan peran sebagai katalisator dalam masyarakat hal ini merupakan bagian dari tugas tafaqu fiddin. 


\section{d. Landasan Yuridis}

UUD 1945 Pasal 31 Ayat 1,2 dan 3 Ayat satu, Setiap warga negara berhak mendapatkan pendidikan, Ayat 2, Setiap warga negara wajib mengikuti pendidikan dasar dan pemerintah wajib membiayainya dan Ayat ke 3, Pemerintah mengusahakan dan menyelenggarakan satu system pendidikan nasional yang meningkatkan keimanan dan ketakwaan serta akhlak mulia dalam rangka mencerdasakan kehidupan bangsa kehidupan bangsa yang diatur dengan undang-undang.

Pasal 1 Ayat 1, dalam Undangundang ini yang dimaksud dengan Pondok pesantren, diniyah, surau, maunasah, atau sebutan lain, yng selanjutnya disebut dengan pesantren adalah sub kultur atau lembaga berbasis masyarakat yang didirikan dengan tujuan untuk menanamkan keimanan dan ketakwaan kepada Allah S.W.T. menyemaikan akhlak, dan membentuk karakter pribadi yang senatiasa memegang teguh ajaran agama, merawat nilai luhur bangsa, dan memiliki orientasi menyelenggarakan pendidikan diniyah atau jenis pendidikan lain untuk mengembangkan kemampuan, pengetahuan, dan keterampilan masyarakat terutama peserta didik dalam memahami dan mengamalkan nilai-nilai ajaran agama dan/atau menjadi ahli ilmu agama, menggerakkan dan menyiarkan dakwah Islam rahmatal lil' alamin, serta sebagai lembaga pemberdayaan sosial ekonomi masyarakat.

Pasal 1 Ayat 6, "Santri adalah peserta didik yang menempuh pendidikan berjengjang atau mendalami ilmu agama Islam di pesantren. Pasal 1 Ayat 7, "Kiayi, tuan guru/gurutta/inyak/syekh, ajengan, ustadz, nyai, ustadzah, atau sebutan lain adalah seorang pendidik yang memiliki kompetensi ilmu agama yang berperan sebagai figur, teladan, dan/atau pengasuh pesantren. Pasal 3 , penyelenggaraan pesantren dan pendidikan keagamaan bertujuan untuk: 1) Membentuk individu yang memahami dan mengamalkan nilainilai ajaran agamanya dan/atau menjadi ahli ilmu agama yang beriman, bertakwa, berakhlak mulia, berilmu, mandiri, ta'awun, tawazun, dan tawasut; 2) Mendorong terbentuknya pemahaman keberagamaan yang moderat cinta tanah air, terwujud kerukunan hidup umat beragama, serta terbentuknya watak peradaban bangsa yang mencerdaskan, bermartabat, dan berkemajuan; 3) Ikut serta dalam 
meningkatkan kualitas hidup masyarakat yang berdaya dalam memenuhi kebutuhan pendidikan warga negara maupun kesejahteraan sosial masyarakat pada umumnya.

Pasal 4, ruang lingkup penyelanggaraan pesantren dan pendidikan keagamaan meliputi pengelolaan: a) Pesantren sebagai lembaga pendidikan, lembaga penyiaran ajaran agama (dakwah Islam, dan lembaga pemberdayaan masyarakat; b) Pendidikan keagamaaan Islam, Kristen, Katolik, Hindu, Buddha, dan Khonghucu (Draft Undang-undang Republik Indonesia tgl 13 September 2018).

Undang-undang Nomor 20 Tahun 2003 tentang Sistem Pendidikan Nasional; Peraturan Pemerintah Nomor 39 Tahun 1992 tentang Peran Serta Masyarakat dalam Pendidikan Nasional; Peraturan Pemerintah No.55 Tahun 2007 tentang Pendidikan Agama dan Keagamaan; Peraturan Pemerintah Nomor 28 Tahun 1990 tentang pendidikan Dasar; Peraturan Pemerintah Nomor 73 tahun 1991 tentang Pendidikan luar sekolah. Peraturan Pemerintah Nomor 23 Tahun 2000 tentang kewenangan Pemerintah Provinsi Sebagai Daerah Otonomi; Peraturan Menteri Agama Nomor 63
Tahun 1983 Tentang Kurikulum Madrasah Diniyah. Keputusan Menteri Agama Nomor 18 Tahun 1985 tentang Susunan Organisasi dan Tata Kerja Departemen Agama yang telah disempurnakan terakhir dengan Keputusan Menteri Agama Nomor 1 Tahun 2001 Keputusan Menteri Agama Nomor 373 Tahun 2002 tentang Organisasi dan Tata Kerja Kantor Wilayah Departemen Agama Provinsi dan Kantor Departemen Agama Kabupaten/Kota. Peraturan Daerah Cianjur Nomor 03 Tahun 2006 tentang Gerakan Pembangunan Masyarakat Berakhlakul Karimah; bagian kelima Pasal 7 Ayat 1 sampai dengan 4 Bidang Pendidikan; Peraturan Bupati Nomor 12 tahun 2006 tentang Pemberdayaan Pendidikan Diniyah yang telah direvisi menjadi Peraturan Bupati Cianjur Nomor 18 tahun 2012 tentang Pemberdayaan Pendidikan Diniyah Takmiliyah dan Pendidikan Al-Qur'an. Peraturan Daerah Nomor 06 Tahun 2016, tentang Wajib Belajar Pendidikan Diniyah Takmiliyah (Perbup No 12 Tahun (2006) Tentang Wajib Belajar Pendidikan Diniyah Takmiliyah di Kabupaten Cianjur) 
e. Visi Misi Pondok Pesantren Salafiyah Al-Intiqol Cianjur

Visi : "Mencetak Ulamaul Amiliin, Ulamaul Muttaqiin, dan Ulamaus Sholihin"

\section{Misi :}

a. Mengoptimalkan Pembelajaran yang aktif, kreatif dan inovatif

b. Menerapkan kedisiplinan

c. Penerapan pembiasaan melakukan shalat tepat waktu d. Membudayakan qiyamu lail

e. Mentdaburkan Al-Qur'an dala keseharian

f. Membudayakan gotong royong

g. Pembinaan pendidikan 24 jam

h. Kegiatan ibadah/ritual yang diberjama'ahkan

i. Pembiasaan pengamalan riyadhoh, istighosah, shalat berjam'ah, tadaraus, muroja'ah, dan shaum sunnah

\section{f. Susunan Kepengurusan Pondok Pesantren Al-Intiqol}

1) Pimpinan Umum

2) Dewan Bid. Pendidikan dan

3) Keamanan

4) Dewan Bid. Kesehatan dan Humas

5) Dewan Bid. Dana Usaha

6) Dewan Bidang Kesantriatan

7) Rois ' $A m$

8) Sekretaris 'Am

9) Bendahara 'Am

10)Wakil Rois 'Am Koor. Putra

11)Wakil Rois 'Am Koor. Putri

12)Sekretaris Koor. Putra

13)Sekretaris Koor. Putri

14) Bendahara Koor. Putri

15) Bendahara Koor. Putri

16) Sie. Pendidikan 'Am
: KH. T. Mukhtar Gozali Ak, S.Sy., M.Si.

: Ust. Aam Nurzaman

: Ust. Asep Zaenal Arifin

: Ust. Lulu Fadlulloh, S. Sy.

: Ustd. Rima Siti Rahmatika Zulda

: Muhammad Nasehudin

: Muhammad Arif Hidayat

: Nina Nurjanah

: Dadang Nurzaman

: Derika Rahim

: a) Hafid Maulana Soleh

: b) Gias Naufal Fahri

: Dini Nuraeni

:a) Miftah As'ari

b) Annida

: Fitriani Anisa Lestari

: a) Hasanudin Sholeh

b) Aris Sutisna 
17) Sie. Pendidikan Koor. Putra
: a) Muhammad Maftuh Fahmi
b) Ahmad Muyasar
c) Ilan Ahmad Zani Dahlan

18) Sie. Pendidikan Koor. Putri

:a) Siti Ulfah

b) Dederika Rahmawati

19) Sie. Keamanan 'Am

: Muhammad As'ad Humam

20) Sie. Keamanan Koor. Putra

: a) Muhammad Zaenudin

b) Ceng-Ceng

c) Ramlan Khofifan

21) Sie. Keamanan Koor. Putri

: a) Siti Ai Mulyati

b) San San Nurhasanah

22) Sie. Kebersihan Koor. Putra
a) Sirojudin Abas
b) Ahmad Sugilar
c) Muhammad Lutfi Fauzi

23) Sie Kebersihan Koor Putri

: a) Ati Supriati

b) Sinta Nuriah

\section{g. Identitas Pondok Pesantren Salafiyah Al-Intiqol}
1) Nama Intansi
: Pondok Pesantren Al-Intiqol
2) Ketua Pimpinan : KH. T. Mukhtar Gozali AK., S.Sy., M.Si.
3) Alamat : Jl. Prof. Moch. Yamin Gg. Darna / JI. KH. Saleh No.10
4) Kelurahan/Desa : Sayang
5) Kecamatan : Cianjur, Cianjur 43213
6) No. Telepon/ HP : : (0263) 265143

\section{h. Program Pondok Pesantren Al-Intiqol}

1) Mencetak Ulamul'amilin

2) Mencetak Imaamul Muttaqin, dan

3) Mencetak Muttaqin 


\section{i. Data Pendidik Pondok Pesantren Al-Intiqol}

Tabel 1

Data Tenaga Pendidik Ponpes Al-Intiqol

\begin{tabular}{|c|l|c|}
\hline No & \multicolumn{1}{|c|}{ Nama Pengajar } & Tingkat Pendidikan \\
\hline 1 & Ust. Lulu Fadlulloh & I lbtida \\
\hline 2 & Ust. Hilman Nurdin, S.Pd. & II lbtida \\
\hline 3 & Dodi Syarifudin & III Ibtida \\
\hline 4 & Ust. Aam Nurzaman & I Tsanawi \\
\hline 5 & Ustd. Diah Rosdiah & II Tsanawi \\
\hline & $\begin{array}{l}\text { KH. T. Mukhtar Gazali Ak., } \\
\text { S.Sy., M.Si. }\end{array}$ & III Tsanawi dan I Ma'had Aly' \\
\hline
\end{tabular}

(Sumber: Data Kesekretariatan Pesantren)

j. Data Santri Pondok Pesantren Al-Intiqol

Tabel 2

Data Santri Ponpes al-Intiqol

\begin{tabular}{|c|c|c|c|c|}
\hline \multirow{2}{*}{ No } & \multirow{2}{*}{$\begin{array}{c}\text { Tingkat } \\
\text { Pendidikan }\end{array}$} & \multicolumn{2}{|c|}{ Jumlah Santri } & Total \\
\cline { 3 - 4 } & Santriwan & Santriwati & Santri \\
\hline 1 & I lbtida & 18 & 20 & 38 \\
\hline 2 & II Ibtida & 12 & 8 & 20 \\
\hline 3 & III Ibtida & 6 & 18 & 24 \\
\hline 4 & I Tsanawi & 3 & 5 & 8 \\
\hline 5 & II Tsanawi & 8 & 4 & 12 \\
\hline 6 & III Tsanawi & - & 1 & 1 \\
\hline 7 & I Ma'had Aly' & 7 & 2 & 9 \\
\hline \multicolumn{2}{|l|}{ Jumlah Keseluruhan } & $\mathbf{5 4}$ & $\mathbf{5 8}$ & $\mathbf{1 1 2}$ \\
\hline
\end{tabular}

(Sumber: Data Kesekretariatan Pesantren 


\section{k. Sarana dan Prasarana Pondok Pesantren Al-Intiqol}

Tabel 3

Data Sarpras ponpes Al-Intiqol

\begin{tabular}{|c|l|c|}
\hline No & \multicolumn{1}{|c|}{ Nama Sarana } & Jumlah \\
\hline 1 & Asrama Putra & 3 lantai \\
\hline 2 & Asrama Putri & 2 \& 3 lantai \\
\hline 3 & Ruang Belajar & 7 unit \\
\hline 4 & Ruang Serbaguna (Pendopo) & 1 unit \\
\hline 5 & Kantor Kesekretariatan & 1 unit \\
\hline 6 & Masjid & 2 lantai \\
\hline 7 & Aula Madrosah & 2 lantai \\
\hline 8 & Dapur Umum & 1 unit \\
\hline
\end{tabular}

(Sumber: Data Kesekretariatan Pesantren)

\section{Kegiatan Santri Pondok Pesantren Al-Intiqol}

Tabel 4

Daftar Kegiatan Santri Ponpes Al-Intiqol

\begin{tabular}{|c|c|c|}
\hline No & Waktu Kegiatan & Jenis dan Pengisi Kegiatan \\
\hline 1 & Kegiatan Harian & Diisi oleh Santri \\
\hline 2 & Kegiatan Mingguan & Diisi oleh Umum \\
\hline 3 & Kegiatan Bulanan & Diisi oleh Orang tua Santri dan Alumn \\
\hline 4 & Kegiatan Tahunan & $\begin{array}{l}\text { a. Peringatan Maulid Nabi dan } \\
\text { Isro Mi'raj } \\
\text { b. Semester Ganjil dan Genap } \\
\text { bagi Santri } \\
\text { c. Penyembelihan Hewan Qurban } \\
\text { d. Sunatan Masal } \\
\text { e. SANLAT (Santri Kilat) } \\
\text { f. Kuliah Subuh di Bulan } \\
\text { Ramadhan } \\
\text { g. Diklat pengkajian kitab } \\
\text { Ushuludin } \\
\text { h. Wisuda Para Santri }\end{array}$ \\
\hline
\end{tabular}

(Sumber: Data Kesekretariatan Pesantren) 
m. Waktu Kegiatan Pondok Pesantren Al-Intiqol

Tabel 5

Jadwal Kegiatan Pembelajaran di Ponpes Al-al-Intiqol Cianjur

\begin{tabular}{|c|c|c|}
\hline No & Waktu & Nama Kegiatan \\
\hline 1 & 03.30-04.30 WIB & $\begin{array}{l}\text { Tahajud dan Tadarus } \\
\text { Berjamaah, Shalat Subuh }\end{array}$ \\
\hline 2 & 04.30-06.00 WIB & Penerapan Nahwu/Shorof \\
\hline 3 & 06.00-07.00 WIB & Kajian Tafsir Jalalain \\
\hline 4 & 07.00-08.30 WIB & $\begin{array}{l}\text { Mandi, Makan, Shalat Duha, dan } \\
\text { Tadarus }\end{array}$ \\
\hline 5 & 08.30-10.00 WIB & Belajar Kitab Kuning \\
\hline 6 & 10.00-12.00 WIB & Istirahat/Kaelulah \\
\hline 7 & 12.00-13.00 WIB & Sholat Dzuhur dan Tadarus \\
\hline 8 & 13.00-14.30 WIB & Belajar Kitab Kuning \\
\hline 9 & 14.30-15.00 WIB & Istirahat \\
\hline 10 & 15.00-16.00 WIB & Shalat Ashar dan Makan \\
\hline 11 & 16.00-17.00 WIB & Belajar Kitab Kuning \\
\hline 12 & 17.00-18.30 WIB & Shalat Magrib dan Tadarus \\
\hline 13 & 18.30-20.30 WIB & Belajar Kelas \\
\hline 14 & 20.30-22.00 WIB & Menghafal Bersama \\
\hline 15 & 22.00-03.30 WIB & Istirahat (Tidur) \\
\hline
\end{tabular}

(Sumber: Data Kesekretariatan Pesantren)

n. Kegiatan Tambahan

Tabel 6

Materi Kuliah Umum Ponpes Al-Intiqol Cianjur

\begin{tabular}{|c|l|l|}
\hline No & Jenis Kegiatan & \multicolumn{1}{|c|}{ Materi Pembelajaran } \\
\hline 1 & Kuliah Umum & a. Tafsir Jalalain \\
& & b. Sulamutaufiq \\
& & c. Kajian Kitab Tasawuf \\
& & d. Pengembangan Tilawatil Al-Qur'an \\
& & e. Pelatihan Da'wah/ Khutbah \\
& & f. Diklat dan FORDISI (Forum Diskusi \\
& & Al-Intiqol) \\
\hline
\end{tabular}

(Sumber: Data Kesekretariatan Pesantren) 


\section{o. Tingkat dan Jenjang Pendidikan Pondok Pesantren Al-Intiqol}

Tabel 7

Jenjang Pendidikan di Ponpes Al-Intiqol Cianjur

\begin{tabular}{|l|l|l|l|}
\hline No & Jenjang Pendidikan & Tingkat Pendidikan & \multicolumn{1}{|c|}{ Waktu } \\
\hline 1 & Ma'hadul Ibtida & I l lbtida & 1Tahun \\
\cline { 3 - 4 } & & II Ibtida & 1 Tahun \\
\cline { 3 - 4 } & & III Ibtida & 1 Tahun \\
\hline 2 & \multirow{2}{*}{ Ma'hadu Tsanawi } & I Tsanawi & 1 Tahun \\
\cline { 3 - 4 } & & II Tsanawi & 1 Tahun \\
\cline { 3 - 4 } & & III Tsanawi & 1 Tahun \\
\hline 3 & \multirow{2}{*}{ Ma'hadul A'ly } & I Ma'hadul A'ly & 1 Tahun \\
\cline { 3 - 4 } & & II Ma'hadul A'ly & 1 Tahun \\
\cline { 3 - 4 } & & III Ma'hadul A'ly & 1 Tahun \\
\hline
\end{tabular}

(Sumber: Data Kesekretariatan Pesantren)

\section{p. Materi Pembelajaran}

Tabel 8

Jadwal Pembelajaran Tambahan

\begin{tabular}{|c|c|c|}
\hline No & Tingkat Pendidikan & Materi Pembelajaran \\
\hline 1 & I lbtida & $\begin{array}{l}\text { a. BTQ dan Tajwid Al-Qur'an } \\
\text { b. Hafalan Juz A'mma } \\
\text { c. Fiqih Ibadah/Ringkasan } \\
\text { Safinah dan Do'a } \\
\text { d. Syahadataen/ Tijan Addaruri } \\
\text { e. Nahwu Dasar/ Jurumiah } \\
\text { f. Khulasoh Juz } 1 \\
\text { g. Akhlaqul Banin Juz } 1\end{array}$ \\
\hline 2 & II Ibtida & $\begin{array}{l}\text { a. Syarah Tijan Addaruri } \\
\text { b. Syarah Jurumiah } \\
\text { c. Syarah Safinatunnaja } \\
\text { d. Tasrifan } \\
\text { e. Tajwid dan Hafalan Juz } \\
\text { A'mma }\end{array}$ \\
\hline
\end{tabular}




\begin{tabular}{|c|c|c|}
\hline & & $\begin{array}{ll}\text { f. } & \text { Khulasoh Juz II } \\
\text { g. } & \text { Akhlaqul Banin Juz II }\end{array}$ \\
\hline 3 & III Ibtida & $\begin{array}{l}\text { a. Majmu'atul Aqidah } \\
\text { b. Shorof } \\
\text { c. Riyadulbadi'ah } \\
\text { d. Qiyasan } \\
\text { e. Hadits Arbain } \\
\text { f. Khulasoh Juz III } \\
\text { g. Akhlaqul Banain Juz II }\end{array}$ \\
\hline 4 & I Tsanawi & $\begin{array}{l}\text { a. Kifayatul Awam } \\
\text { b. Alfiyah Ibnu Malik } \\
\text { c. Bajuri } \\
\text { d. Faroid/ Ruhbiyah } \\
\text { e. Hadits Riyadussolihin } \\
\text { f. Nasoihul 'Ibad }\end{array}$ \\
\hline 5 & II Tsanawi & $\begin{array}{l}\text { a. Jauhar Tauhid } \\
\text { b. I'anatutolibin I\&II } \\
\text { c. Isti'arah } \\
\text { d. Hadits Bukhori I\&II } \\
\text { e. Sirojutolibin } \\
\text { f. Mabade Awaliyah }\end{array}$ \\
\hline 6 & III Tsanawi & $\begin{array}{l}\text { a. Ummul Barohim } \\
\text { b. l'anatutolibin III\&IV } \\
\text { c. Hadits Bukhori III\&IV } \\
\text { d. Kifayatul Akhyar } \\
\text { e. Lathoiful Isyaroh (Ushul } \\
\text { Fiqih) } \\
\text { f. Goyatul Wusul (Ushul Fiqih) } \\
\text { g. Sulamunawaroh (Mantiq) }\end{array}$ \\
\hline 7 & I Ma'hadul A'ly & $\begin{array}{l}\text { a. Samarqondi } \\
\text { b. Jauhar M'anun } \\
\text { c. Qulyubi I\&II } \\
\text { d. Hadits Muslim }\end{array}$ \\
\hline
\end{tabular}




\begin{tabular}{|l|l|l|}
\hline 8 & II Ma'hadul A'ly & e. Al-Hikam Ibnu Athoillah \\
\hline & & $\begin{array}{l}\text { a. Uqudul Juman } \\
\text { b. Baiquniyah }\end{array}$ \\
& & c. Qulyubi III\&IV \\
& d. Mukhtasor Syafi \\
& Ma'hadul A'ly & e. Taqribul Maqsud \\
& & b. Sam'ul Jawami \\
& & c. Fathul Wahab \\
& d. Ihya U'lumudin \\
& e. Sulamunairen
\end{tabular}

(Sumber: Data Kesekretariatan Pesantren)

\section{SIMPULAN}

Kesimpulan yang dapat diambil sejalan dengan fokus penelitian dan pembahasan dalam penelitian ini sebagai berikut:

Pertama, Kegiatan pembelajaran dengan menggunakan kurikulum mandiri yang disusun langsung oleh Kiyai dan para Asatidz di lingkungan Pondok Pesantren Salafiyah Al-Intiqol Cianjur. Selanjutnya penerapan standar kompetensi yang diunggulkan rancangan dan menindaklanjuti program-program terdahulu dengan berbagai kegiatan terutama dalam hal evaluasi. Kedua, Melaksanakan berbagai program sesuai yang direncanakan dalam visi dan misi serta tujuan pondok pesantren, yakni: pembinaan keagamaan, pembinaan kedisiplinan, pembinaan karakter sebagai calon ulama masa depan yang memiliki kompetensi Ulamaul Amiliin, Ulamaul Muttaqiin dan Ulamaus Sholihin serta dapat mengaplikasikannya dalam tafaquh fiddin, Ketiga, dalam proses Pembelajaran menggunakan metode atau model, leadership (sistem lurah santri), kemandirian, ceramah interaktif, sorogan, talaqi, tasmi, muroja'ah, imla, Muhadhoroh, Diskusi, dan lain sebagainya, Keempat, mencetak santri berkompetensi dan berkepribadian yang Ulamaul Amiliin, Ulamaul Muttaqiin, dan Ulamus Sholihin serta dapat mengaplikasikannya dalam kehidupan kesehariannya Kelima, untuk mengetahui cara mengevaluasi hasil 
pembelajaran santri di Pesantren AlIntiqol yaitu: pengawasan pelaksanaan evaluasi pembelajaran baik harian, mingguan, bulanan, triwulanan, semesteran dan tahunan pada pelaksanaan pembelajaran di Pondok Pesantren A-Intiqol dengan tujuan untuk meningkatkan mutu pendidikan kepesantrenan yang diambil dari sumber, Al-Qur'an, As-Sunnah, dan kitab-kitab kuning demi tercapainya tujuan pendidikan dalam upaya peningkatan sumber daya manusia yang masih lemah, sehingga perlu dilakukan evaluasi.

\section{DAFTAR PUSTAKA:}

Daulay, H.P.(2007). Sejarah Pertumbuhan dan Pembaharuan Pendidikan Islam di Indonesia. Jakarta: Prenada Media, 2007.

Dhofier, Z. Tradisi Pesantren Studi Tentang Pandangan Hidup Kyai. Jakarta: LP3ES.

Wahid, A. (1995). Pesantren Sebagai Sub Kultur dalam M.Dewan
Rahardjo (ed) Pesantren dan Pembaharuan. Jakarta: LP3ES.

Daulay H.P., S. P. (2005). Jejak Intelektual Asritek Pesantren. Jakarta: Prened

U.-u. R. (2003). Tentang Sistem Pendidikan Nasional dan Penjelasannya. Jakarta: CV, Eko Jaya.

Zarkasy Steenbrink, K.A. (1998). pesantren, Sekolah, Pendidikan Islam Kurun Modern. Jakarta LP3ES : LP3ES Cet ke 2

Madjid, N. (1997). Bilik-bilik Pesantren Sebuah Potret Perjalanan. Jakarta: Paramadian.

Hakim, L. (2016). Hari Santri Nasional. Jakarta: Kemenag RI

Dadan, E.S. (2008). Ngaguar mamaos Cianjuran,. Cianjur: Lembaga Kebudayaan Cianjur.

Jurnal Pusaka 16 juli-desember 2015, Modernisasi pendidikan Pesantren dalam pesktif Abdurrahman Wahid.

Draft Undang-undang Republik Indonesia tgl 13 September 2018

Perbup No 12 Tahun. (2006). Tentang Wajib Belajar Pendidikan Diniyah Takmiliyah di Kabupaten Cianjur. 